\title{
Desalination in the Context of Water Scarcity Crisis: Dares \& Perspectives
}

\author{
Djamel Ghernaout ${ }^{1,2}$, Noureddine Elboughdiri1,3 \\ ${ }^{1}$ Chemical Engineering Department, College of Engineering, University of Ha'il, Ha'il, KSA \\ ${ }^{2}$ Chemical Engineering Department, Faculty of Engineering, University of Blida, Blida, Algeria \\ ${ }^{3}$ Chemical Engineering Process Department, National School of Engineering, Zrig Gabes 6029, University of Gabes, Gabes, Tunisia \\ Email: *djamel_andalus@hotmail.com
}

How to cite this paper: Ghernaout, D. and Elboughdiri, N. (2020) Desalination in the Context of Water Scarcity Crisis: Dares \& Perspectives. Open Access Library Journal, 7: e6963.

https://doi.org/10.4236/oalib.1106963

Received: November 5, 2020

Accepted: November 21, 2020

Published: November 24, 2020

Copyright (C 2020 by author(s) and Open Access Library Inc.

This work is licensed under the Creative Commons Attribution International License (CC BY 4.0).

http://creativecommons.org/licenses/by/4.0/ (cc) (i) Open Access

\begin{abstract}
Throughout the world, providing drinking water via desalination engineering becomes a more and more adopted option. With quickly progressing desalination engineering and market maturation, desalination prices are fast dropping, and the ecological effects of desalination are steadily relieved. Even if desalination is probably to stay more costly in nearly all areas than conventional water provision solutions, it could turn into progressively a solution to satisfy inevitable deficiencies for particular markets. Consequently, desalination has to be employed strategically inside a combined water-planning program. This work discusses desalination as a practicable option to reduce a water provision-need vacuum and its techniques and features. Ecological duties should force a huge extension of used water gathering and handling; further, increasing water shortage and prices could render used water reuse growingly a profitable solution. Nontraditional solutions like wastewater reuse and desalination have to be considered jointly to deal with water shortage. Improving adopted technologies and increasing allocated funds to these future and indispensable nontraditional solutions remain unavoidable. Secured technologies like membrane processes should be largely applied throughout the world to secure potable water for all humankind.
\end{abstract}

\section{Subject Areas \\ Chemical Engineering \& Technology}

\section{Keywords}

Desalination, Seawater (SW), Brackish Water (BW), Thermal Desalination, Membrane Desalination, Water Provision-Need Vacuum 


\section{Introduction}

Around three-quarters of the worldwide inhabitants stay below water shortage [1] [2] [3]. In several regions, withdrawals really surpass the employable water, deteriorating the reservoir. In fact, a general "mining" of nonrenewable groundwater exists. Most of the earth's aquifers become in danger [4]. Contaminating watercourses has damaged the quality and rendered them no longer available for use [1] [5].

As a matter of demand, demographic stresses and increasing degrees of usage worsen shortage [1]. In term of supply, pressures are as well getting larger with lower accessibility since precipitation patterns vary, moreover, warming augments evaporation and demand [6] [7] [8]. Lack of adequate water delivery seriously influences populous regions especially if water supply is limited [9] [10] [11].

In fact, many solutions, conventional and nontraditional, to decrease the water provision-need vacuum exist [1]. Such options deal with the sides of handling water for fair use and ecological preservation [12]. Those strategies precisely handle lack by means of improved performance and engineering (comprising usage of desalination) and via safeguard of the resource's standard and volume [13] [14].

The simplest option remains to let performance ameliorations in cultivation and manufacture [15] [16] [17]. For several nations, the nearly all inexpensive options stay in cultivation [18] [19] [20]. Additional options are more and more suggested via integrating enhanced efficacy of water supply and utilization [1] [21] [22] [23] [24] [25].

Even with constant ameliorations in water treatment, at the actual speed of turn, many efforts remain to be accomplished. Several nations suffering water shortage have started applying procedures to handle supply and demand, and in some situations, have reached noteworthy positive result. Nevertheless, the proportion of advance generally remains comparatively lazy [1].

Solutions focusing on provision stay restricted; further solutions confront ascendant prices. Chances for exploiting the lasting natural waters that could be sustainably and economically developed remain restricted [26] [27]. Solutions concentrating on infrastructure ameliorations will reduce around $20 \%$ of the void separating provision and need [1]. Provision as well confronts dangers from global warming [28] [29]. Dropped precipitation and increasing temperatures could more decrease the reliable resource.

Under the present state, the water provision-need vacuum could not be reduced; further, water crisis coupled with ecological damage may aggravate [1].

Since stresses surpass, novel techniques will more and more add to the renewable resource [1]. Throughout the world, only around three-quarters of the freshwater taken away is consumed, and the remaining quarter is given back to nature in the form of used water. In fact, such used water constitutes a chance to augment water accessibility, especially if used water is well treated [30] [31] [32]. Ecological duties will progressively force a huge extension of gathering and pu- 
rifying used water; moreover, increasing water shortage and prices could render used water reemployment growingly a profitable solution [33] [34] [35].

For particular markets and areas, desalination will stay the adopted technique [2] [13] [36]. With quickly progressing desalination engineering and market maturation, desalination prices are fast dropping, and the ecological effects of desalination are steadily relieved [14]. Even if there is more probability that desalination stays more costly than conventional water provision solutions, it can turn into progressively a solution to satisfy inevitable deficiencies for particular markets [14]. Consequently, desalination has to be employed strategically inside a combined water planning program [1] [14].

Combined water planning is obligatory to deal with such a water provision-need vacuum. What is learned from the worrying likelihood of an ever-increasing provision-need vacuum is that water stays a central section of a nation's strategy. In fact, organizing inside the water-employing sectors should be merged inside the total organization and the set of performance and supervision-amelioration actions needed must be supported and encouraged [1]. Otherwise, water quantities and prices must be taken into account for better organization.

Based mainly on the important solutions (desalination is one of them), upcoming water schemes could be suggested for a specific nation [1] [2] [13]. Employing an iterative process, nations could propose water scenarios from which to make a map of routes of development that equilibrate water provision and need. Such schemes can comprise the water need consequences. The water provision-need vacuum under each scheme could be determined. The solutions to reducing the void could therefore be defined and classified by price. At such a step, the range for nontraditional solutions like wastewater reuse and desalination will be estimated [2] [13] [14].

Planning procedures and the manner by which desalination is combined with them are well explained by researchers [1]. Such a type of combined organization is more than requested [2] [13] [14].

Desalination has to participate in decreasing the space between provision and need in the next decades [2] [13] [14]. Even if the plurality of the provision-need vacuum options stay arising from the conventional provision and need-side handling solutions mentioned above, researchers [1] focused on desalination as one of the workable choices. The cause for this is that deficiency is augmenting almost. Now, more than 150 nations are so soon employing desalination to satisfy specific parts of need [1].

The present work discusses desalination as a practicable choice to decrease a water provision-need vacuum and its techniques and features. Desalination costs are also reviewed. An outlook on the next trends is also given especially for technologies and prices. A comparison between desalination and water reuse is shortly presented. A brief discussion about some facts that nature comprises innate desalination engineering is briefly given. In the Middle East, thermal desalination plants are prevailing; however, such a situation is tending to be reversed in the benefit of membrane processes. 


\section{Desalination as a Workable Solution to Reduce a Water Provision-Need Vacuum}

\subsection{Desalination Elucidated}

From salty water fountains, mostly seawater (SW) or brackish water (BW), desalination (also named "desalinization") forms freshwater [1]. Nature provides numerous illustrations of desalination.

BW sources possess mostly local capacity; however, the prime raw material, SW, is relatively boundless. Desalinated water is generated from BW (salinity more than $500 \mathrm{mg} / \mathrm{L}$ and less than $30,000 \mathrm{mg} / \mathrm{L}$ ) or from SW (salinity more than $30,000 \mathrm{mg} / \mathrm{L}$ and less than $44,000 \mathrm{mg} / \mathrm{L}$ ). Desalination of BW provides chances to generate lower-cost water than SW desalination. Even if BW's sources may be locally considerable, its capacity is restricted by obtainable amounts (the global volume of BW is less than $1 \%$ of the Earth's water). Moreover, the oceans hold around $97 \%$ of the Earth's water reservoirs and so give a boundless raw material [1].

\subsection{Secured Water Provision Solution: Desalination}

Comparatively to different water provision technologies, desalination remains more expensive. Further, it requires a judicious application. Such technique could generate high-quality drinking water that equips the demands of huge cities [1] [37].

Pushed by increasing need and engineering progresses, desalination price dropped quickly during the last twenty years. However, the direction toward bigger plants has brought very important economies of scale. Consequently, desalination prices have downed from a usual domain of US $\$ 2.50 / \mathrm{m}^{3}$ to US $\$ 4.00 / \mathrm{m}^{3}$ in the 1980 s to prices that presently average less than US $\$ 1.50 / \mathrm{m}^{3}[1]$.

Consequently, desalination is beginning to be a more and more reasonably priced solution for over 150 countries that employ this technique to generate freshwater. Two years ago, around 20,000 desalination facilities were working worldwide, generating 90 million cubic meters per day of treated water each day (for around 300 million people). In fact, water treated by desalination actually constitutes almost $1 \%$ of the globe's potable water [1] [38].

In spite of that, prices remain generally bigger than alternatives; this is why desalination in most cases stays a strategic solution. Even if the prices of desalination have decreased speedily (Figure 1), they stay nearly constantly bigger relatively to the prices of treating surface water or groundwater [1]. Figure 1 shows an acute decrease in price of desalination since the 1960s. Such technology may be adopted as a feasible choice to close the water provision-need vacuum.

\section{Desalination Techniques and Their Features}

As a rule, in terms of engineering classes, desalination may be realized via thermal process or membrane process for removing salts from water [1]. In fact, 


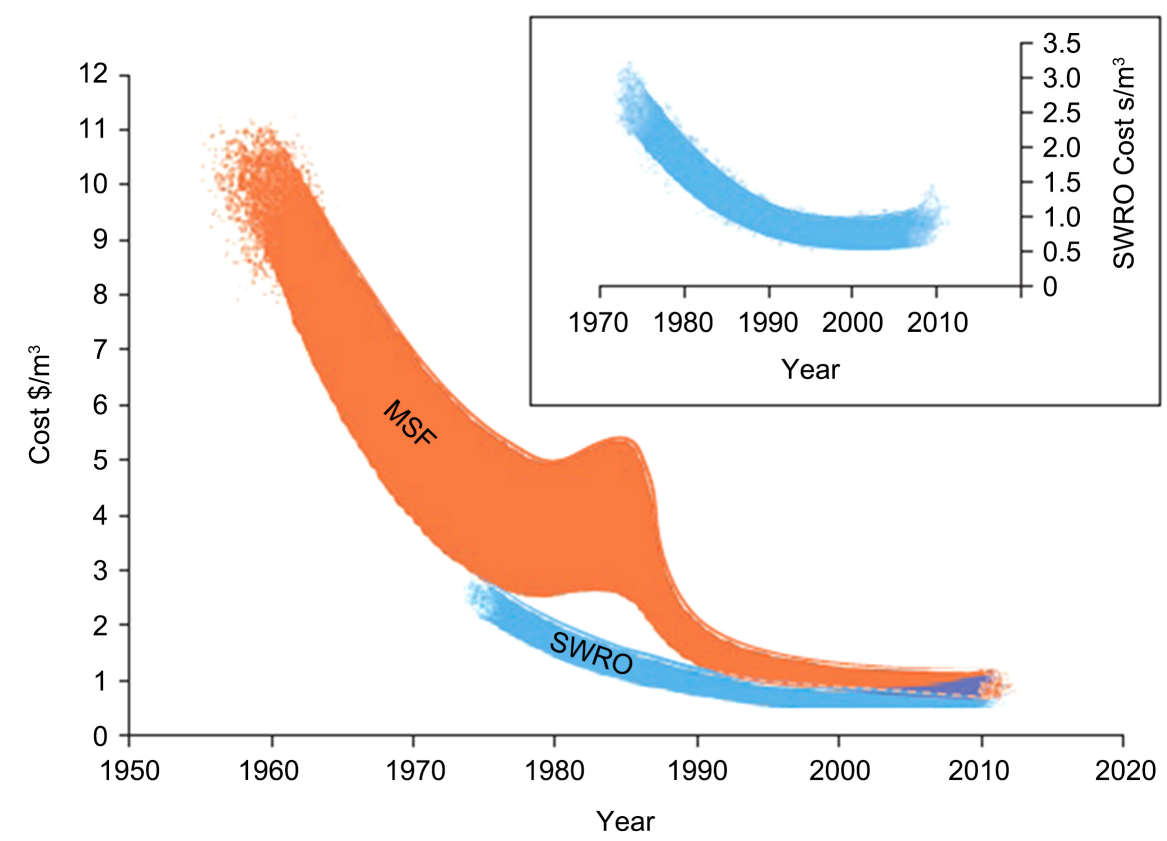

Figure 1. Price tendencies for Seawater Reverse Osmosis (SWRO) and Multistage Flash Distillation (MSF) techniques [37].

numerous desalination techniques are below investigation and numerous methods are in the expansion phase (however, the only two that are presently commercially applicable and largely employed remain evaporation and membrane separation processes). Before twenty years, water was mostly desalinated throughout the world by thermal evaporation. Nonetheless, lately, engineering's ameliorations in RO desalination reached a fast elevation in the number of factories employing membrane method. Indeed, membrane technology represents $65 \%$ of the desalination capacity through the globe, while thermal technology attracts the remaining part (additional techniques like electrodialysis reversal (EDR) and vapor-compression (VC) distillation drive a low fraction of the market) $[1]$.

\subsection{Desalination via Thermal Heating}

Desalination employing heating (boiling, evaporating, and condensing) is the earliest technique utilized for removing salts from water on an industrial scale. In terms of fundamental idea, it concerns exerting heat to form vapor from water. Such vapor is condensed into clean water, salts and pollutants are removed. In matter of thermal processes configurations, Multistage Flash Distillation (MSF) and Multiple Effect Distillation (MED) remain the most frequently utilized thermal techniques [1] [13].

\subsubsection{Multistage Flash Distillation (MSF)}

Among desalination techniques, MSF remains the most durable. In addition, it stays the most efficient and dealing with huge production capabilities. MSF method comprises a set of steps or cells kept at reducing pressures starting from the 
first step (hot) to the last one (cold). As shown in Figure 2, SW flows in on the right side via tubes in the upper part of the chambers where it is warmed by the water vapor formed in each stage.

More details that are technical may be found elsewhere [1].

\subsubsection{Multiple Effect Distillation (MED)}

Identically to MSF, MED functions like a phenomenon founded on evaporation. The saline water passes via a set of chambers. Each successive chamber runs at a gradually lower pressure. During the MED method, the vapor produced in one chamber condenses in the following chamber with the heat-liberated working as a heating source. Further, feed water is generally sprayed over the tube bundle at the top of each chamber (the dark blue track in Figure 3).

Descriptions that are more technical may be found elsewhere [1].

\subsubsection{Multiple Effect Distillation (MED) with Thermal Vapor Compressor (TVC)}

Increasing Multiple Effect Distillation (MED) performance could be elevated by introducing a vapor compressor. Indeed, a Thermal Vapor Compressor (TVC) could be combined with a MED setup to extract part of the steam produced in the final chamber for reuse. The extracted steam will be combined with the external steam for compression below high pressure, which then functions as a heating source in the first chamber. Since such amelioration could lead to considerable energy cost savings, MED-TVC appears as the most broadly utilized MED technique contemporarily [1].

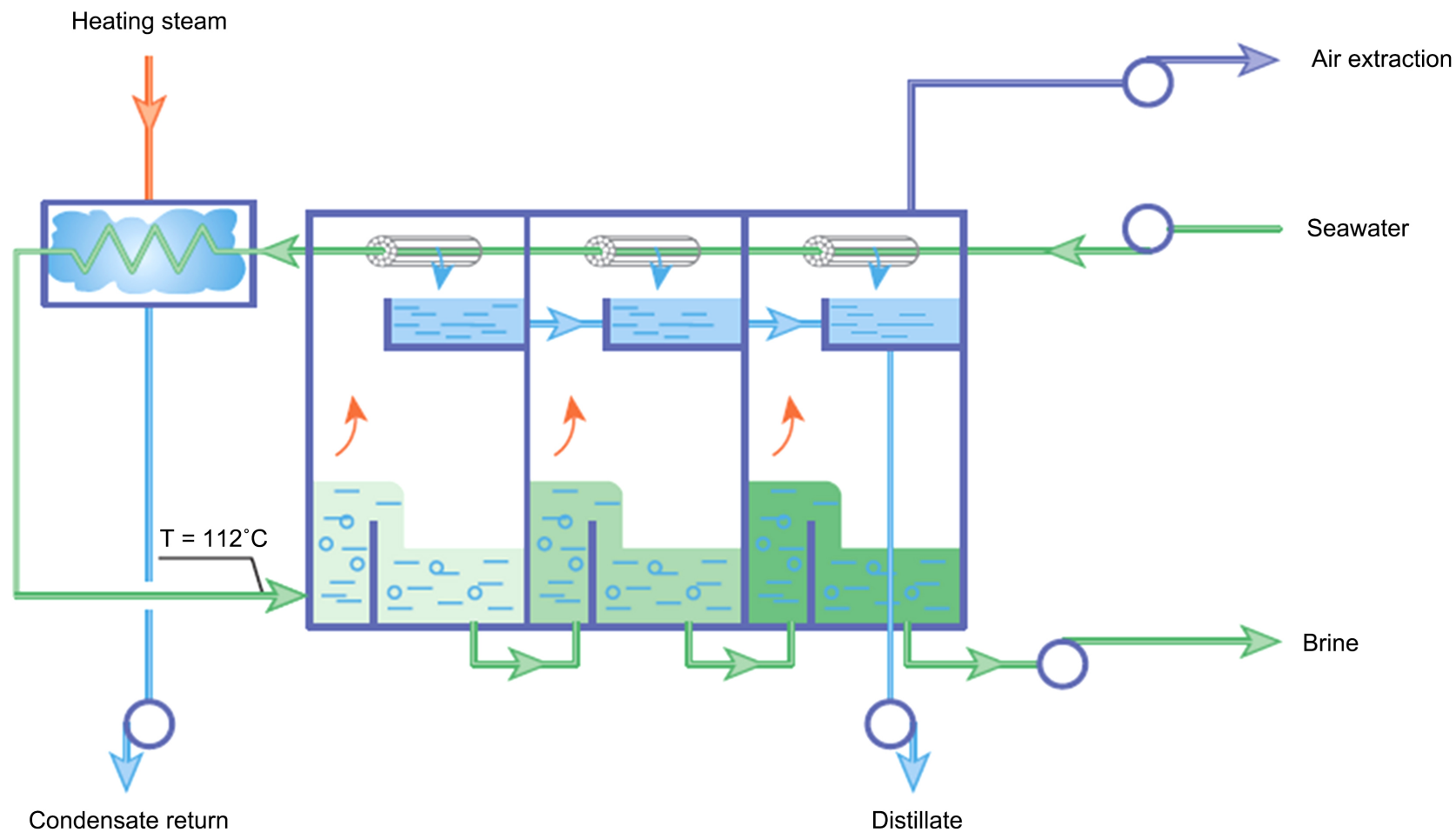

Figure 2. Global scheme of a Multistage Flash Distillation (MSF) facility [1]. 


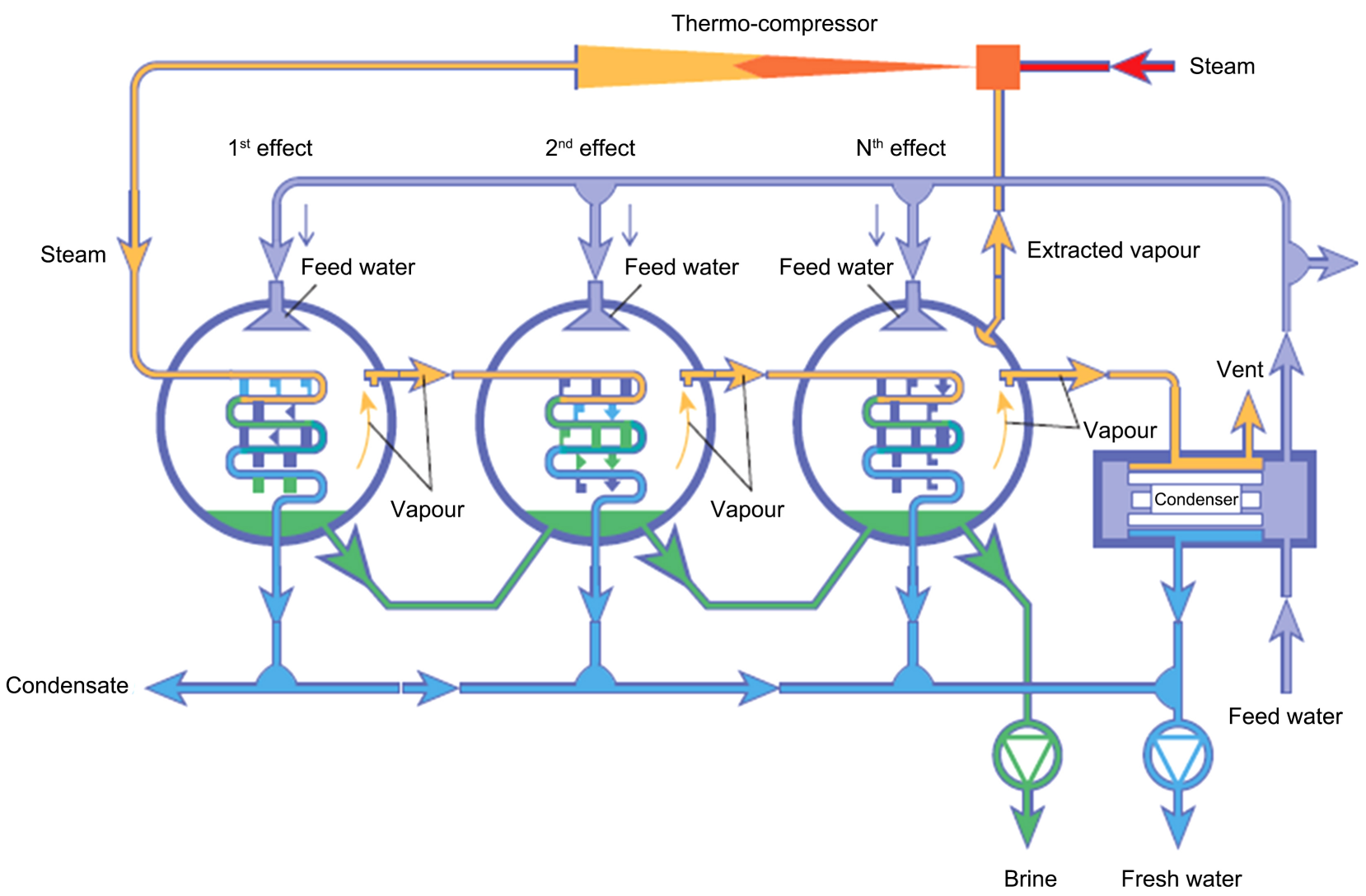

Figure 3. Illustration of Multiple Effect Distillation (MED) desalination technique [1].

\subsection{Membrane Desalination}

Membrane techniques adopt the natural phenomenon of osmosis. In fact, membranes have a crucial contribution in separating salts in natural phenomena like osmosis and dialysis. Such a concept has been adopted for industrial usage in water treatment via developing membranes that selectively let or block salts diffusion. Industrially obtainable membrane methods comprise reverse osmosis (RO), nanofiltration (NF), electrodialysis (ED), and EDR. RO is presently the only membrane technique utilized. The remaining membrane techniques are not widely applied at the industrial level. In fact, NF and RO use pressure; however, ED and EDR employ electrical current for removing salt [1].

RO remains a frequently employed technique for treating water. It uses a semipermeable membrane to eliminate mainly ions, molecules, and bigger particles [39]. During RO passage, an implemented pressure is utilized to beat osmotic pressure, which is due to chemical potential dissimilarities of water [40]. As an example, in the case of SW (i.e., salinity of $35,000 \mathrm{mg} / \mathrm{L}$ ) on one part of the membrane and potable water (i.e., salinity of $500 \mathrm{mg} / \mathrm{L}$ ) on the remaining part of the membrane, the osmotic pressure formed on the membrane is around 24 bars [1].

RO could retain several sorts of solubilized and suspended chemical substances as well as biological ones (mostly microbe) from water [39] [40]. This is 
why it is utilized in desalinating and treatment water fields. The solute is kept on the pressurized part of the membrane and the pure water is left to go to the other part. Such membrane must not permit big molecules to pass across the pores; however, it has to authorize smaller water molecules to go readily [1].

As illustrated in Figure 4, the feed water is pumped below great pressure across a semipermeable membrane to retain concentrate (or brine [41]) from purified water [1] [39] [40].

Since its name implicates, the RO process is adverse to what takes place in osmosis. A pressure bigger than the osmotic pressure is implemented to saline water. As a result, freshwater flows over the membranes and salts are retained. An elevated-pressure pump pushes saline water at around 65 - 75 times the atmospheric pressure towards semipermeable membranes. The membranes are developed to authorize $\mathrm{H}_{2} \mathrm{O}$ molecules to go across them whilst keeping solubilized salts. The RO technique could be utilized both for Seawater Reverse Osmosis (SWRO) desalination and for desalination of BW (brackish water reverse osmosis, BWRO). Usually, $40 \%-60 \%$ of the SW introduced into a membrane process is recuperated as purified water. For BW desalination, water recuperation could fluctuate from $50 \%$ to $90 \%$ [1] [39] [40].

Seeing that RO membranes could be blocked readily by dispersed matters and mineral scaling substances, RO devices need particular equipment not employed in thermal desalination devices to prepare the source SW [21] [41] [42]. Further, purified water after that goes through additional stage (known as post-treatment, mostly composed of $\mathrm{pH}$ adjustment and disinfection [43] [44] [45]), to render it appropriate for human consumption [1] [40] [46].

Membrane techniques may as well be utilized for treating wastewater [1] [47] [48]. Indeed, membrane processes could be employed not only for removing salts from BW or SW supplies but also for dealing with used water thanks to their potential to as well retain pollutants other than salts (e.g., organic pollutants [49] [50] [51], microalgae [52] [53] [54], bacteria [55] [56] [57], and viruses [58] [59] [60]).

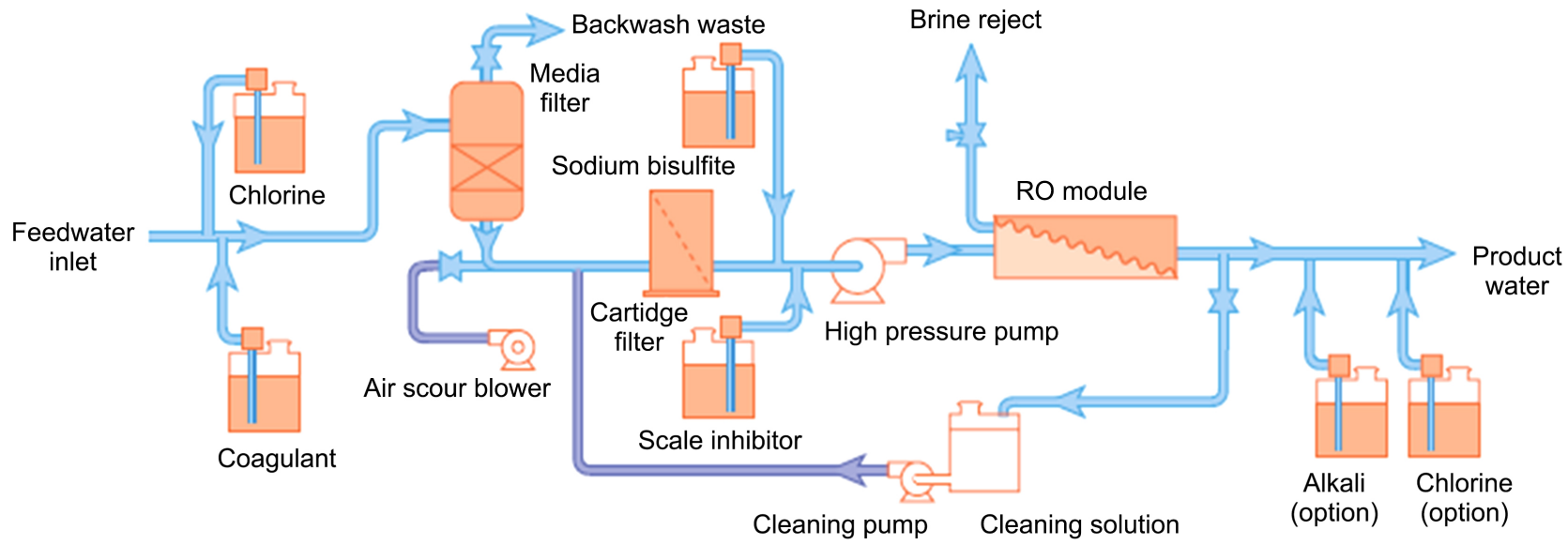

Figure 4. Illustration of the Reverse Osmosis (RO) desalination technique [1]. 


\subsection{Combined Processes}

Combined desalination plants mix thermal desalination facility (either MSF or MED) and an SWRO desalination setup. The merged thermal and SWRO plants are usually co-located with a power generation station; further, they share a joint intake and outfall. Hybrids are mostly adopted if there is a large change in power or water demand need diurnally or between seasons. This permits the combined plant to benefit from cheap energy when it is accessible; however, to satisfy needed degrees of water production via switching between SWRO and thermal technology following which system provides the cheapest product at the time. Since such a strategy needs accurate planning for the equilibrating of water and power supply and need at the least cost, it is commonly unsuitable for "retrofitting" onto present power production facilities. Frequently, hybrids constitute part of a novel build merged water and power generation complex expanded as an "independent water and power project" [1].

\subsection{Expansion Patterns of the Frequently Employed Desalination Techniques}

SWRO has surpassed thermal method. Now it constitutes two-thirds of used capacity throughout the world. Until 2000's, thermal technology (especially MSF) was the most frequently employed technique. Employing SWRO technology has speeded up during the ultimate twenty years thanks to its lower energy usage and progresses in applied techniques (especially membrane processes and pretreatment method) [41] that have rendered it very ruthless, even in the highly saline SWs in which thermal technologies were previously more ruthless. Six years ago, the SWRO technique constituted almost $63 \%$ of the global desalination capacity (Figure 5), pursued by MSF (23\%) and MED (8\%). ED, hybrids, and other technologies took the remaining $6 \%$ desalination capacity [1] [61].

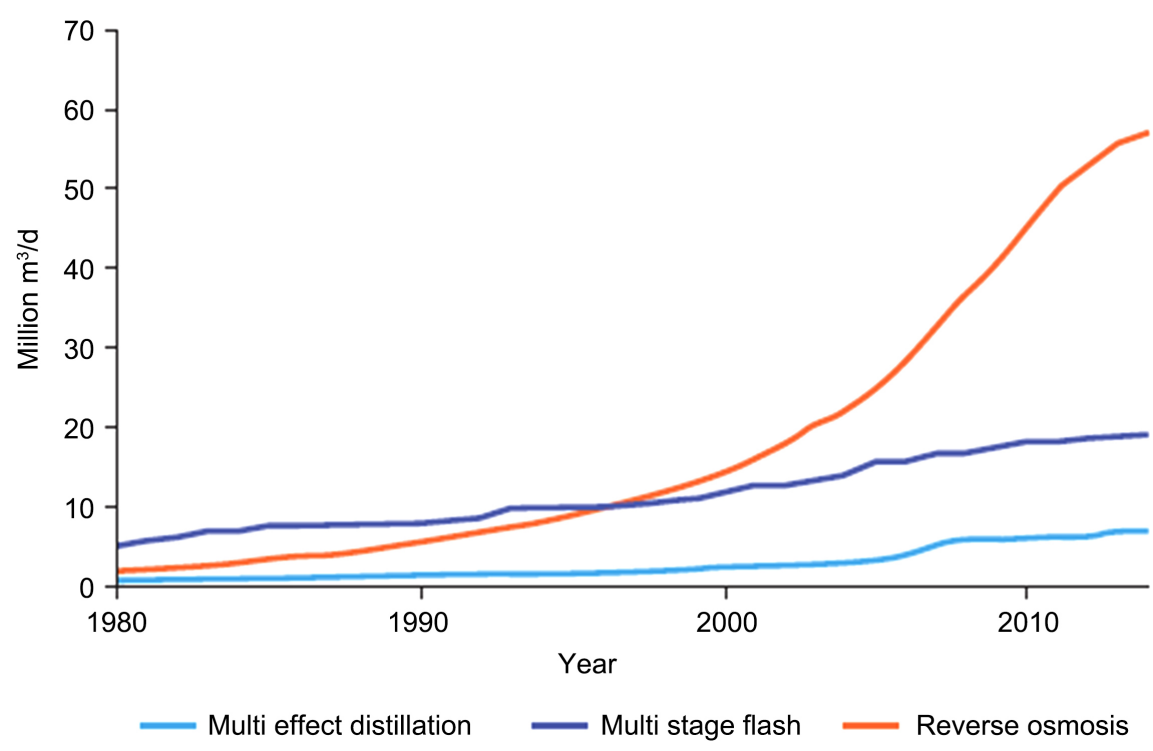

Figure 5. Global cumulative capacity of SW desalination by technology, 1980-2014 [1]. 


\section{Desalination Prices}

As a rule, overall costs have been quickly decreasing. Indeed, new usual prices of water treatment depict large decreases for MSF and MED, but in particular, for SWRO that is presently knowing costs around US\$ $0.64 / \mathrm{m}^{3}$. Researchers [1] formed a database including more than fifty desalination projects throughout the globe built during the previous twenty years (Table 1). As an illustration, Table 1 presents the real prices of desalination following method and feed water reservoir for SWRO factories [1].

\section{Future Trends}

\subsection{Nature Includes Innate Desalination Engineering}

As the main part of the water cycle, evaporating water over the oceans and seas stays the most evident natural phenomenon for removing salts from water (Figure 6) [1] [13] [62]. More details about the simulation of the open sky SW distillation may found elsewhere [13].

One more phenomenon remains the generation of sea ice. Such phenomenon forms ice with a little salt that is much lower than that in SW [1]. Desalination takes also place in the plant world (Figure 7) [63]. Indeed, mangrove trees grow in SW, liberating the salt in their roots and leaves. Further, willow trees and reeds absorb salt and additional pollutants, successfully removing salt from water. Such a natural desalination phenomenon is exploited in industrially constructed wetlands for dealing with urban used water [1].

Astonishingly, the animal world could as well desalinate. Seabirds like pelicans, petrels, albatrosses, gulls, and terns distill SW utilizing a gland that liberates highly concentrated brine near the nostrils above the beak. The bird then "sneezes" the brine out. This lets birds to drink salty water from the ocean while they are far from land [1].

Table 1. Summary of worldwide SW desalination prices (Costs are at 2016 estimates. MED-TVC = Multiple Effect Distillation with Thermal Vapor Compression; MLD = million liters per day; MSF = Multistage Flash Distillation; O\&M = Operation and Maintenance; SWRO = Seawater Reverse Osmosis) [1].

\begin{tabular}{|c|c|c|c|c|c|c|}
\hline \multirow{2}{*}{ Desalination technology } & \multicolumn{2}{|c|}{$\begin{array}{c}\text { Capital costs } \\
\text { (million US\$/MLD) }\end{array}$} & \multicolumn{2}{|c|}{$\begin{array}{l}\text { O\&M costs } \\
\left(\mathrm{US} \$ / \mathrm{m}^{3}\right)\end{array}$} & \multicolumn{2}{|c|}{$\begin{array}{l}\text { Cost of water production } \\
\left(\mathrm{US} \$ / \mathrm{m}^{3}\right)\end{array}$} \\
\hline & Range & Average & Range & Average & Range & Average \\
\hline MSF & $1.7-3.1$ & 2.1 & $0.22-0.30$ & 0.26 & $1.02-1.74$ & 1.44 \\
\hline MED-TVC & $1.2-2.3$ & 1.4 & $0.11-0.25$ & 0.14 & $1.12-1.50$ & 1.39 \\
\hline SWRO (Arabian Gulf) & $1.2-1.8$ & 1.5 & $0.36-1.01$ & 0.64 & $0.96-1.92$ & 1.35 \\
\hline SWRO (Red Sea) & $1.2-2.3$ & 1.5 & $0.41-0.96$ & 0.51 & $1.14-1.70$ & 1.38 \\
\hline SWRO (Atlantic and Pacific Oceans) & $1.3-7.6$ & 4.1 & $0.17-0.41$ & 0.21 & $0.88-2.86$ & 1.82 \\
\hline MSF/MED & $1.5-2.2$ & 1.8 & $0.14-0.25$ & 0.23 & $0.95-1.37$ & 1.15 \\
\hline
\end{tabular}




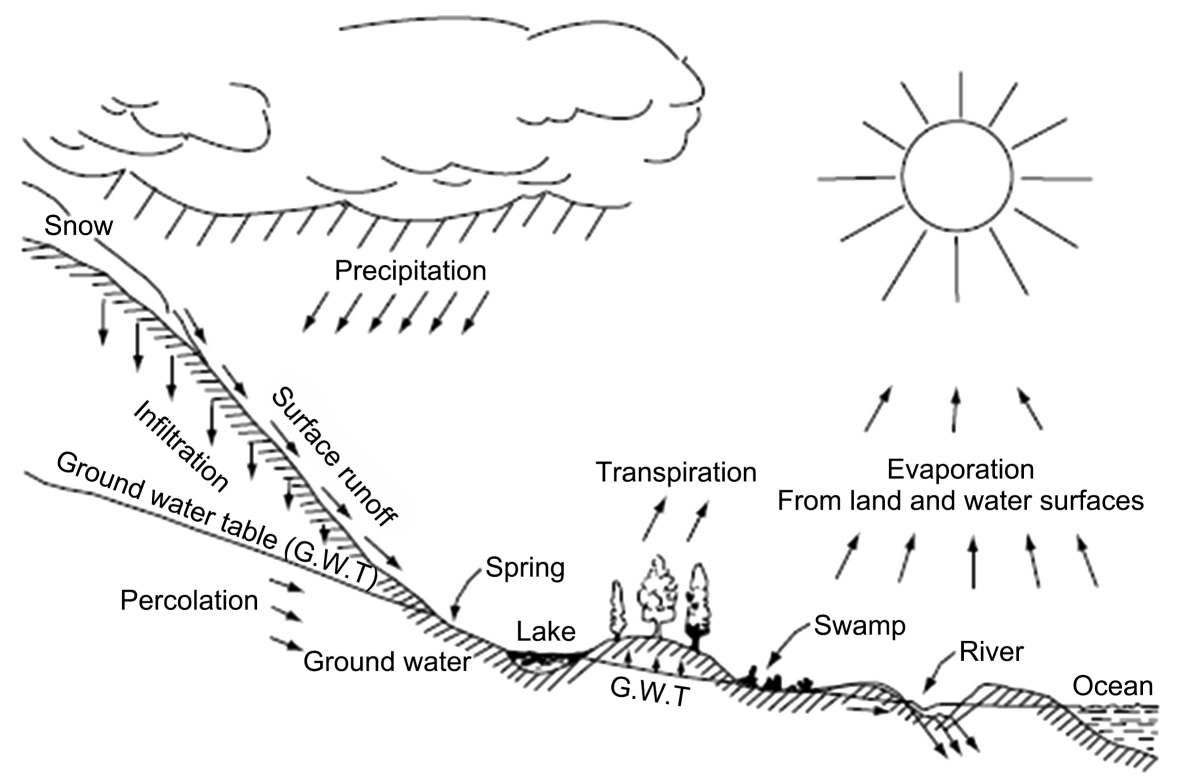

Runoff or stream flow

= Surface runoff and ground-water runoff

Figure 6. The hydrologic cycle [62].

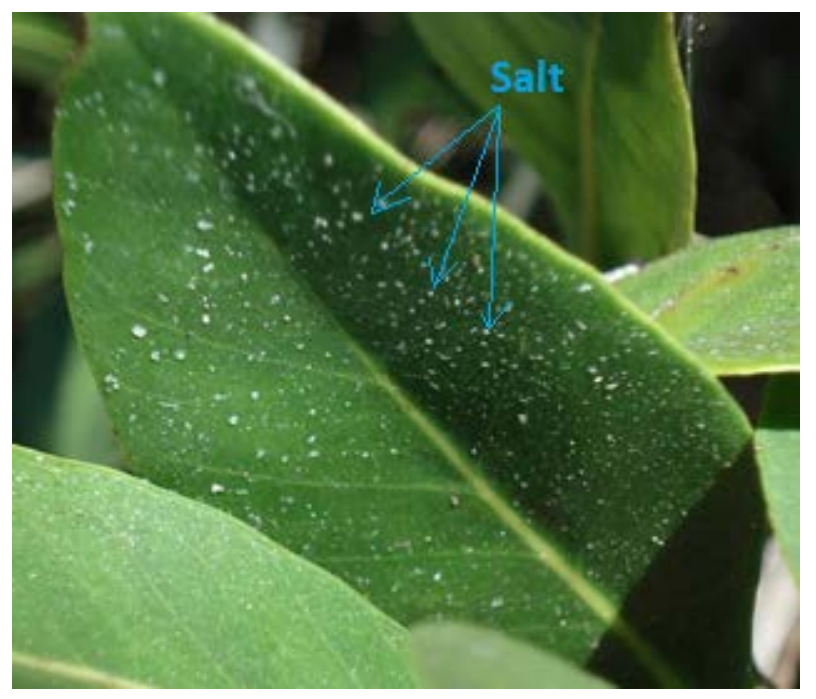

Figure 7. Salt crystals on Black Mangrove [63].

\subsection{Prevailing Thermal Desalination Plants in the Middle East: Towards Its Reversal in the Benefit of Membrane Processes}

Thermal techniques are utilized everywhere in the Middle East [1]. It is possible that such technologies will persist to be famous in the area for numerous causes. The regional seas are highly saline and warm, and periodically have elevated levels of organic matter, which are hard conditions for membrane desalination engineering. Further, thermal techniques could employ low-temperature waste steam from power production turbines; consequently, colocation of desalination and power production for considerable efficiency savings, profiting from shared intake and discharge structures as well as increasing energy efficiencies (mostly 
by $15 \%)$. Such causes, merged with the low-cost energy in the region, render thermal techniques a more interesting desalination technique in such a region than in most other areas. Moreover, membrane plants have only lately attained the huge generation capabilities requested in such an area.

However, such a tendency may be reversed towards membrane techniques due to global warming gases, as thermal desalination employs oils to get energy at least it will use solar energy [64] [65].

\subsection{Outlooks for Technologies and Prices}

Desalination engineering has ameliorated, and prices persist to down greatly [1]. From 1980 to 2005, the price of desalination dropped by more than half (Figure 8). Even if desalination stays costly juxtaposed to traditional water treatment techniques, more decreases in prices are possibly to close the space more in the next twenty years. Such progresses are most probably to be in desalination engineering, in pretreatment [66] [67] [68], in brine management [14] [46], and in energy efficiency and sourcing [2] [29] [36].

Additional huge price discounts are predictable, especially for SWRO, in which prices are awaited to more drop by up to two-thirds during the following twenty years thanks to technological ameliorations in membrane design and system integration [1].

\subsubsection{Progresses in Traditional Desalination Methods}

While only comparatively restricted additional amelioration in thermal techniques is anticipated, elevating performance in fundamental price elements will persist to render SWRO more competitive. Among such cost-decreasing ingredients has been the amelioration in membrane productivity that has doubled during the last two decades. Ameliorations are continuing apace, as freshly expanded membrane elements give flexibility and choice and allow trade-offs

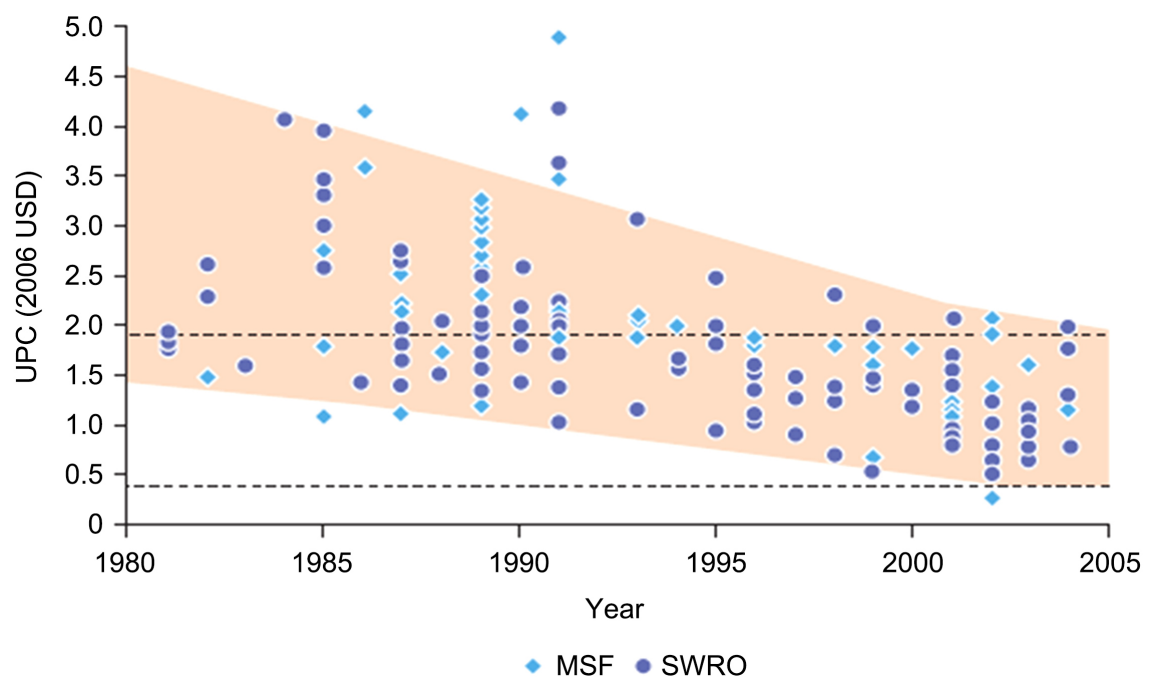

Figure 8. Trends in the cost of desalination of Multistage Flash (MSF) distillation and Seawater Reverse Osmosis (SWRO) plants [1]. 
among productivity and energy prices. In fact, such ameliorations in membrane performance rather than in energy recovery that are anticipated to support the position of SWRO as the most cost-competitive process in most circumstances [1].

\subsubsection{Arising Technical Progress with Elevated Desalination Price Lowering Possibility}

In addition to the technical ameliorations previously anticipated under frequently utilized desalination techniques, several fresh methods or adaptations are arising, which could provide the potential for even bigger productivity and lower prices (Table 2).

Table 2. New techniques or readjustments apt for giving the possibility for bigger productivity and lower prices [1].

\begin{tabular}{|c|c|}
\hline Fresh method or readjustment & Description \\
\hline Nanostructured membranes & $\begin{array}{l}\text { Such membranes possess until } 20 \% \text { bigger productivity } \\
\text { than traditional ones, or they could function at the } \\
\text { identical productivity but employ until } \\
15 \% \text { less energy. }\end{array}$ \\
\hline Carbon nanotubes & $\begin{array}{c}\text { If carbon nanotubes with much bigger productivity could } \\
\text { be suggested, then this may slash desalination prices to } \\
\text { the level of traditional water treatment techniques } \\
\text { during ten years. }\end{array}$ \\
\hline Forward osmosis $(F O)$ & $\begin{array}{l}\text { Such type of osmosis, presently utilized mostly for } \\
\text { industrial wastewater treatment, is being expanded for } \\
\text { drinking water, with the capacity to decrease energy } \\
\text { use until one-third. }\end{array}$ \\
\hline Membrane distillation (MD) & $\begin{array}{l}\text { Such version of distillation technology can mainly } \\
\text { double the recovery ratio from SW } \\
\text { (from } 45 \%-50 \% \text { to } 80 \% \text { ). }\end{array}$ \\
\hline Dewvaporation & $\begin{array}{c}\text { Dewvaporation, a low-temperature, low-price evaporation } \\
\text { technique at an early step of expansion, can diminish } \\
\text { the prices of thermal evaporation until one-quarter, } \\
\text { especially in hot, dry regions. }\end{array}$ \\
\hline Adsorption techniques & $\begin{array}{l}\text { Such methods could decrease scaling and corrosion in } \\
\text { thermal plants, even if the techniques remain costly. }\end{array}$ \\
\hline Electrochemical desalination & $\begin{array}{c}\text { Electrochemical desalination can considerably decrease } \\
\text { prices until 15\%via more efficacious energy usage. }\end{array}$ \\
\hline Capacitive deionization (CDI) & $\begin{array}{l}\text { CDI can bring priced is counts until one-third if the } \\
\text { numerous technique dares could be beat to render } \\
\text { it a main stream solution. }\end{array}$ \\
\hline $\begin{array}{l}\text { Biomimetic membranes with } \\
\text { aquaporin structures }\end{array}$ & $\begin{array}{l}\text { These membranes, which are membranes modeled on those } \\
\text { of living organisms, can furnish the ultimate breakthrough } \\
\text { in low-energy desalination. Intensive research is } \\
\text { undertaken; however, it stays in the early steps. }\end{array}$ \\
\hline
\end{tabular}


The possible influence of technology expansion is spectacular and can cut SWRO prices by half or more in the next decade. Present tendencies in the depression of the desalination price, and the augmenting prices of the alternatives, are possible to persist, and it is not unlikely that cost decreases of $20 \%$ during 5 years will be encountered for SWRO and 60\% in 20 years [1] [70].

\section{Desalination vs. Water Reuse}

Researchers [69] confronted the cost of water reuse to the cost of SW desalination. With a view to treating water of equivalent quality, an RO stage was introduced to the process flow diagrams shown in Figure 9 [16] [69]. In this situation, $\mathrm{RO}$ is required to eliminate dissolved organic carbon and residual nutrients like nitrate [16] [69]. For desalination, it was supposed that surface SW (TDS of $35,000 \mathrm{mg} / \mathrm{L}$ ) was pretreated via coagulation and multi-media filtration before RO. The process flow diagrams are illustrated in Figure 10 and the parameters employed for the two techniques are confronted in Table 3.

(a)

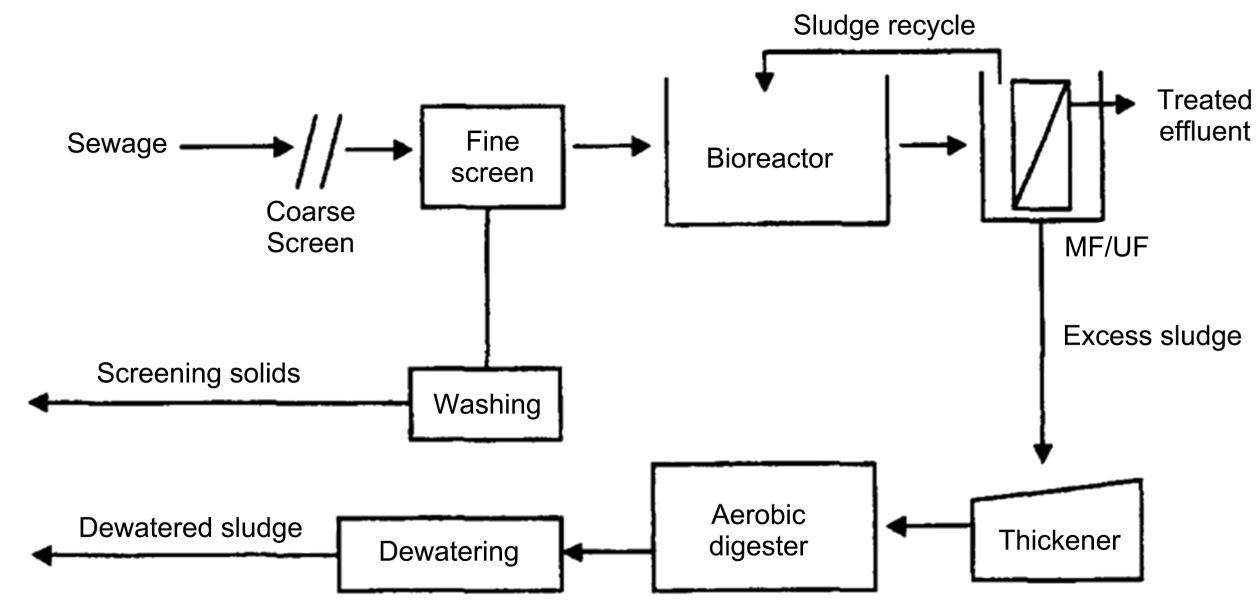

(b)

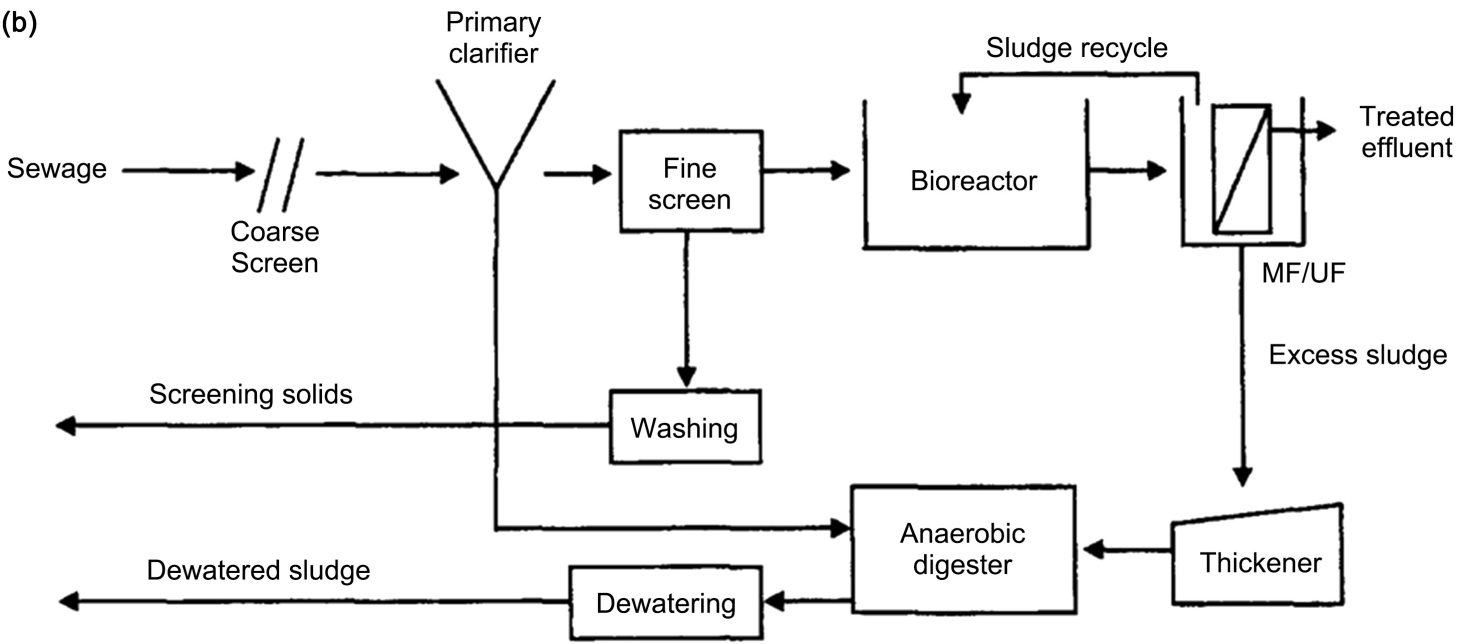

Figure 9. Process flow diagram for the membrane bioreactor option (MBR): (a) small plants; (b) large plants [69]. 
(a)
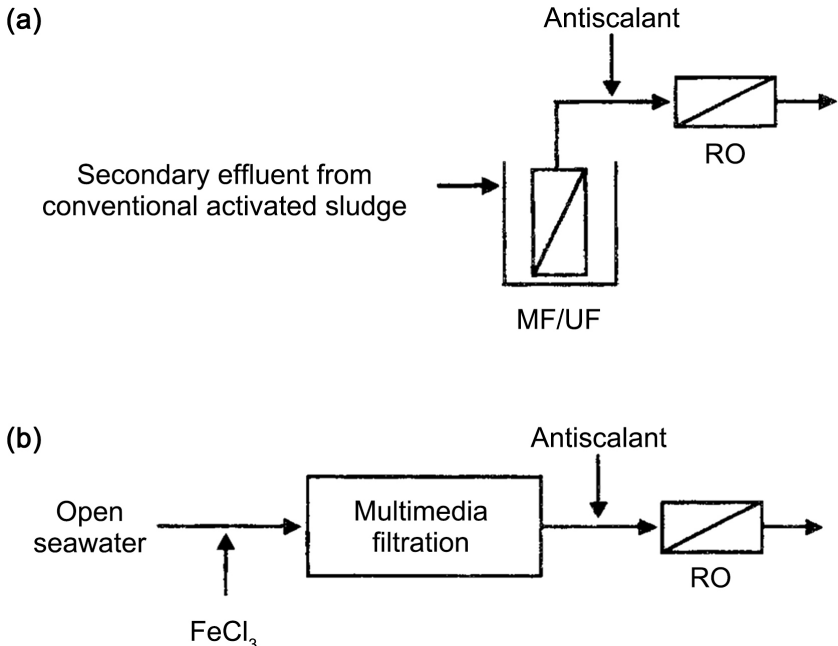

Figure 10. Process flow diagrams for comparison of water reuse and SW desalination: (a) water reuse; (b) SW desalination [69].

Table 3. Design process parameters for the RO facilities (MBR $=$ Membrane Bioreactor, CAS-TF effluent $=$ Conventional Activated Sludge + Tertiary Membrane Filtration) [69].

\begin{tabular}{cccc}
\hline Unit process & Parameter & Water reuse (WR) & Desalination \\
\hline Coagulation & $\mathrm{FeCl}_{3}$ dose, $\mathrm{mg} / \mathrm{L}$ & No & 5 \\
Pretreatment & & MBR or CAS-TF effluent & Multimedia filtration \\
Anti-scalant addition & Dose, $\mathrm{mg} / \mathrm{L}$ & 2 & 5 \\
& Stages, number & 2 & 2 \\
Reverse osmosis (RO) & Recovery, $\%$ & 75 & 50 \\
& Flux, L/m²/h & 20 & 13 \\
& Feed pressure, bar (psi) & $13.6(200)$ & $68(1000)$
\end{tabular}

The total costs evaluated for treating RO water from secondary effluent and from SW are confronted in Table 4 for $38,000 \mathrm{~m}^{3} / \mathrm{d}$ facilities. The costs in column A do not comprise the cost linked to conventional activated sludge (CAS) since it was supposed that sewage would be treated to that degree for discharge; for simplicity, the cost for tertiary filtration assessed previously were employed as pretreatment cost for RO. It was hypothesized that the concentrate from both plants may be disposed of at no cost [16] [69].

The capital costs for a factory treating water from SW are around 50\% more elevated than the costs of a factory reusing secondary sewage. Both the pretreatment costs and RO costs are more elevated. In the situation of pretreatment, this is attributed to the void in recuperation (75\% for secondary effluent; $50 \%$ for SW), which conducts to a bigger SW setup. The capital cost for the SWRO process is bigger than for the secondary effluent RO since it is working at a much more important pressure, lower permeate flux, lower recovery, and should be constituted of materials that resist corrosion in SW [69]. 
Table 4. Costs of treating water from secondary effluent and from SW for a 38,000 $\mathrm{m}^{3} / \mathrm{d}$ factory [69].

\begin{tabular}{cccc}
\hline Component & A: from CAS effluent & B: from SW & Ratio (B/A) \\
\hline Capital costs, $\$ / \mathrm{m}^{3} / \mathrm{d}$ & & & \\
Pretreatment & 161 & 238 & 1.48 \\
Reverse osmosis (RO) & 321 & 492 & 1.53 \\
Total & 482 & 730 & 1.51 \\
Total life cycle costs, $\$ / \mathrm{m}^{3}$ & & & \\
Capital & 0.07 & 0.10 & 1.51 \\
Operation and maintenance (O\&M) & 0.21 & 0.60 & 2.86 \\
Total & 0.28 & 0.70 & 2.50 \\
\hline
\end{tabular}

In the same way, the O\&M costs for treating RO water from SW are around 3 times bigger than the cost of reusing secondary sewage. The bigger pretreatment costs are linked to chemicals, the continuous dosage of a coagulant and more important dosage of antiscalant. The bigger RO costs are linked mainly to energy (the working pressure is five times bigger and the feed flow is 1.5 times more important), but also to membrane replacement [69].

The total life cycle costs for treating RO water from secondary effluent and SW are $0.285 / \mathrm{m}^{3}$ and $0.705 / \mathrm{m}^{3}$, respectively, a ratio of 2.55 [69].

\section{Conclusions}

This work discussed desalination as a practicable solution to close a water provision-need vacuum and its techniques and features. Desalination costs are also reviewed. An outlook on the next trends is also given. A comparison between desalination and water reuse is shortly presented. From this review, the following conclusions arise:

Ecological duties should force a huge extension of wastewater collection and treatment, and increasing water shortage and prices will render wastewater reuse growingly an economic solution; it so far is in so water-short nations. Even if desalination is probably to stay more costly in most areas than conventional water supply solutions, it will turn into progressively a solution to satisfy inevitable deficiencies for particular markets. Nontraditional solutions like wastewater reuse and desalination have to be considered jointly to deal with water shortage. Improving adopted technologies and increasing allocated funds to these future and indispensable nontraditional solutions remain unavoidable. Secured technologies like membrane processes should be largely applied throughout the world to secure potable water for all humankind.

\section{Acknowledgements}

The Research Deanship of University of Ha'il, Saudi Arabia, has funded this re- 
search through the Project RG-20 113.

\section{Conflicts of Interest}

The authors declare no conflicts of interest regarding the publication of this paper.

\section{References}

[1] World Bank (2019) The Role of Desalination in an Increasingly Water-Scarce World. Washington DC.

[2] Irki, S., Kasbadji-Merzouk, N., Hanini, S. and Ghernaout, D. (2020) Modelling of the Coupling of Desalination Plants with the Thermal Solar Energy System. Water Supply, 20, 1807-1822. https://doi.org/10.2166/ws.2020.092

[3] McDonald, R.I., Weber, K., Padowski, J., Florke, M., Schneider, C., Green, P.A., Gleeson, T., Eckman, S., Lehner, B., Balk, D., Boucher, T., Grill, G. and Montgomery, M. (2014) Water on an Urban Planet: Urbanization and the Reach of Urban Water Infrastructure. Global Environmental Change, 27, 96-105. https://doi.org/10.1016/j.gloenvcha.2014.04.022

[4] Richey, A.S., Thomas, B.F., Lo, M.-H., Reager, J.T. and Famiglietti, J.S. (2015) Quantifying Renewable Groundwater Stress Using GRACE. Water Resources Research, 51, 5217-5238. https://doi.org/10.1002/2015WR017349

[5] Ghernaout, D. and Ghernaout, B. (2020) Controlling COVID-19 Pandemic through Wastewater Monitoring. Open Access Library Journal, 7, e6411.

https://doi.org/10.4236/oalib.1106411

[6] Veldkamp, T.I.E., Wada, Y., Aerts, J.C.J.H. and Ward, P.J. (2016) Towards a Global Water Scarcity Risk Assessment Framework Incorporation of Probability Distributions and Hydro-Climatic Variability. Environmental Research Letters, 11, Article ID: 024006. https://doi.org/10.1088/1748-9326/11/2/024006

[7] Ghernaout, D. and Elboughdiri, N. (2020) Domestic Wastewater Treatment: Difficulties and Reasons, and Prospective Solutions-China as an Example. Open Access Library Journal, 7, e6141.

[8] Ghernaout, D. and Elboughdiri, N. (2020) Urgent Proposals for Disinfecting Hospital Wastewaters during COVID-19 Pandemic. Open Access Library Journal, 7, e6373. https://doi.org/10.4236/oalib.1106373

[9] Ghernaout, D., Alshammari, Y. and Alghamdi, A. (2018) Improving Energetically Operational Procedures in Wastewater Treatment Plants. International Journal of Advanced and Applied Sciences, 5, 64-72. https://doi.org/10.21833/ijaas.2018.09.010

[10] Ghernaout, D., Elboughdiri, N. and Ghareba, S. (2020) Fenton Technology for Wastewater Treatment: Dares and Trends. Open Access Library Journal, 7, e6045. https://doi.org/10.4236/oalib.1106045

[11] Ghernaout, D. and Elboughdiri, N. (2020) Advanced Oxidation Processes for Wastewater Treatment: Facts and Future Trends. Open Access Library Journal, 7, e6139.

[12] Ghernaout, D. (2017) Environmental Principles in the Holy Koran and the Sayings of the Prophet Muhammad. American Journal of Environmental Protection, 6, 75-79. https://doi.org/10.11648/j.ajep.20170603.13

[13] Ghernaout, D. (2013) The Best Available Technology of Water/Wastewater Treatment and Seawater Desalination: Simulation of the Open Sky Seawater Distillation. 
Green and Sustainable Chemistry, 3, 68-88. https://doi.org/10.4236/gsc.2013.32012

[14] Ghernaout, D. (2020) Desalination Engineering: Environmental Impacts of the Brine Disposal and Their Control. Open Access Library Journal, 7, e6777.

[15] Ghernaout, D. (2017) Water Reuse (WR): The Ultimate and Vital Solution for Water Supply Issues. International Journal of Sustainable Development Research, 3, 36-46. https://doi.org/10.11648/j.ijsdr.20170304.12

[16] Ghernaout, D., Elboughdiri, N. and Al Arni, S. (2019) Water Reuse (WR): Dares, Restrictions, and Trends. Applied Engineering, 3, 159-170.

[17] Ghernaout, D., Elboughdiri, N. and Ghareba, S. (2019) Drinking Water Reuse: One-Step Closer to Overpassing the "Yuck Factor". Open Access Library Journal, 6, e5895. https://doi.org/10.4236/oalib.1105895

[18] Al Arni, S., Amous, J. and Ghernaout, D. (2019) On the Perspective of Applying of a New Method for Wastewater Treatment Technology: Modification of the Third Traditional Stage with Two Units, One by Cultivating Microalgae and Another by Solar Vaporization. International Journal of Environmental Sciences \& Natural Resources, 16, Article ID: 555934. https://doi.org/10.19080/IJESNR.2019.16.555934

[19] Ghernaout, D. (2019) Reviviscence of Biological Wastewater Treatment-A Review. Applied Engineering, 3, 46-55.

[20] Ghernaout, D. and Elboughdiri, N. (2019) Upgrading Wastewater Treatment Plant to Obtain Drinking Water. Open Access Library Journal, 6, e5959.

https://doi.org/10.4236/oalib.1105959

[21] Ghernaout, D., Alshammari, Y., Alghamdi, A., Aichouni, M., Touahmia, M. and Ait Messaoudene, N. (2018) Water Reuse: Extenuating Membrane Fouling in Membrane Processes. International Journal of Environmental Chemistry, 2, 1-12. https://doi.org/10.11648/j.ajche.20180602.12

[22] Ghernaout, D. (2018) Increasing Trends towards Drinking Water Reclamation from Treated Wastewater. World Journal of Applied Chemistry, 3, 1-9. https://doi.org/10.11648/j.wjac.20180301.11

[23] Ghernaout, D. and Elboughdiri, N. (2020) Electrochemical Technology for Wastewater Treatment: Dares and Trends. Open Access Library Journal, 7, e6020.

[24] Ghernaout, D. and Elboughdiri, N. (2019) Water Reuse: Emerging Contaminants Elimination-Progress and Trends. Open Access Library Journal, 6, e5981.

[25] Ghernaout, D. and Elboughdiri, N. (2020) UV-C/ $/ \mathrm{H}_{2} \mathrm{O}_{2}$ and Sunlight $/ \mathrm{H}_{2} \mathrm{O}_{2}$ in the Core of the Best Available Technologies for Dealing with Present Dares in Domestic Wastewater Reuse. Open Access Library Journal, 7, e6161. https://doi.org/10.4236/oalib.1106161

[26] Ghernaout, D., Ghernaout, B. and Naceur, M.W. (2011) Embodying the Chemical Water Treatment in the Green Chemistry-A Review. Desalination, 271, 1-10. https://doi.org/10.1016/j.desal.2011.01.032

[27] Ghernaout, D. and Ghernaout, B. (2012) On the Concept of the Future Drinking Water Treatment Plant: Algae Harvesting from the Algal Biomass for Biodiesel Production-A Review. Desalination and Water Treatment, 49, 1-18. https://doi.org/10.1080/19443994.2012.708191

[28] Ghernaout, D. and Elboughdiri, N. (2020) Environmental Engineering for Stopping Viruses Pandemics. Open Access Library Journal, 7, e6299.

[29] Ghernaout, D. (2019) Greening Cold Fusion as an Energy Source for Water Treatment Distillation-A Perspective. American Journal of Quantum Chemistry and Molecular Spectroscopy, 3, 1-5. 
[30] Ghernaout, D. and Elboughdiri, N. (2020) On the Treatment Trains for Municipal Wastewater Reuse for Irrigation. Open Access Library Journal, 7, e6088.

[31] Ghernaout, D., Naceur, M.W. and Aouabed, A. (2011) On the Dependence of Chlorine By-Products Generated Species Formation of the Electrode Material and Applied Charge during Electrochemical Water Treatment. Desalination, 270, 9-22. https://doi.org/10.1016/j.desal.2011.01.010

[32] Ghernaout, D. and Naceur, M.W. (2011) Ferrate(VI): In Situ Generation and Water Treatment-A Review. Desalination and Water Treatment, 30, 319-332. https://doi.org/10.5004/dwt.2011.2217

[33] Ghernaout, D., Elboughdiri, N. and Alghamdi, A. (2019) Direct Potable Reuse: The Singapore NEWater Project as a Role Model. Open Access Library Journal, 6, e5980. https://doi.org/10.4236/oalib.1105980

[34] Ghernaout, D. (2020) Water Treatment Challenges towards Viruses Removal. Open Access Library Journal, 7, e6408.

[35] Ghernaout, D. and Elboughdiri, N. (2020) Solar Treatment in the Core of the New Disinfection Technologies. Chemical Science \& Engineering Research, 2, 6-11.

[36] Ghernaout, D., Alghamdi, A., Touahmia, M., Aichouni, M. and Ait Messaoudene, N. (2018) Nanotechnology Phenomena in the Light of the Solar Energy. Journal of Energy, Environmental \& Chemical Engineering, 3, 1-8.

https://doi.org/10.11648/j.jeece.20180301.11

[37] Ghaffour, N., Missimer, T.M. and Amy, G.L. (2013) Technical Review and Evaluation of the Economics of Water Desalination: Current and Future Challenges for Better Water Supply Sustainability. Desalination, 309, 197-207. https://doi.org/10.1016/j.desal.2012.10.015

[38] Voutchkov, N. (2016) Desalination: Past, Present and Future. International Water Association, 17/08/2016. https://iwa-network.org/Desalination,-past-present-future

[39] Ghernaout, D. and El-Wakil, A. (2017) Requiring Reverse Osmosis Membranes Modifications-An Overview. American Journal of Chemical Engineering, 5, 81-88. https://doi.org/10.11648/j.ajche.20170504.15

[40] Ghernaout, D. (2017) Reverse Osmosis Process Membranes Modeling-A Historical Overview. Journal of Civil, Construction and Environmental Engineering, 2, 112-122.

[41] Saiba, A., Kourdali, S., Ghernaout, B. and Ghernaout, D. (2010) In Desalination, from 1987 to 2009, the Birth of a New Seawater Pretreatment Process: Electrocoagulation-An Overview. Desalination and Water Treatment, 16, 201-217. https://doi.org/10.5004/dwt.2010.1094

[42] Ait Messaoudene, N., Naceur, M.W., Ghernaout, D., Alghamdi, A. and Aichouni, M. (2018) On the Validation Perspectives of the Proposed Novel Dimensionless Fouling Index. International Journal of Advanced and Applied Sciences, 5, 116-122. https://doi.org/10.21833/ijaas.2018.07.014

[43] Ghernaout, D. and Ghernaout, B. (2010) From Chemical Disinfection to Electrodisinfection: The Obligatory Itinerary? Desalination and Water Treatment, 16, 156-175. https://doi.org/10.5004/dwt.2010.1085

[44] Boucherit, A., Moulay, S., Ghernaout, D., Al-Ghonamy, A.I., Ghernaout, B., Naceur, M.W., Ait Messaoudene, N., Aichouni, M., Mahjoubi, A.A. and Elboughdiri, N.A. (2015) New Trends in Disinfection By-Products Formation upon Water Treatment. Journal of Research \& Developments in Chemistry, 2015, Article ID: 628833. https://doi.org/10.5171/2015.628833 
[45] Ghernaout, D. (2017) Microorganisms' Electrochemical Disinfection Phenomena. EC Microbiology, 9, 160-169.

[46] Ghernaout, D. (2019) Brine Recycling: Towards Membrane Processes as the Best Available Technology. Applied Engineering, 3, 71-84.

[47] Ghernaout, D., El-Wakil, A., Alghamdi, A., Elboughdiri, N. and Mahjoubi, A. (2018) Membrane Post-Synthesis Modifications and How It Came About. International Journal of Advanced and Applied Sciences, 5, 60-64. https://doi.org/10.21833/ijaas.2018.02.010

[48] Ghernaout, D. (2020) New Configurations and Techniques for Controlling Membrane Bioreactor (MBR) Fouling. Open Access Library Journal, 7, e6579.

[49] Ghernaout, D. and Elboughdiri, N. (2020) Should We Forbid the Consumption of Antibiotics to Stop the Spread of Resistances in Nature? Open Access Library Journal, 7, e6138.

[50] Ghernaout, D. (2018) Disinfection and DBPs Removal in Drinking Water Treatment: A Perspective for a Green Technology. International Journal of Advanced and Applied Sciences, 5, 108-117. https://doi.org/10.21833/ijaas.2018.02.018

[51] Ghernaout, D. and Elboughdiri, N. (2020) Disinfection By-Products (DBPs) Control Strategies in Electrodisinfection. Open Access Library Journal, 7, e6396. https://doi.org/10.4236/oalib.1106396

[52] Ghernaout, D., Elboughdiri, N., Ghareba, S. and Salih, A. (2020) Coagulation Process for Removing Algae and Algal Organic Matter-An Overview. Open Access Library Journal, 7, e6272. https://doi.org/10.4236/oalib.1106272

[53] Ghernaout, B., Ghernaout, D. and Saiba, A. (2010) Algae and Cyanotoxins Removal by Coagulation/Flocculation: A Review. Desalination and Water Treatment, 20, 133-143. https://doi.org/10.5004/dwt.2010.1202

[54] Ghernaout, D., Moulay, S., Ait Messaoudene, N., Aichouni, M., Naceur, M.W. and Boucherit, A. (2014) Coagulation and Chlorination of NOM and Algae in Water Treatment: A Review. International Journal of Environmental Monitoring and Analysis, 2, 23-34. https://doi.org/10.11648/j.ijema.s.2014020601.14

[55] Ghernaout, D. and Elboughdiri, N. (2020) Dealing with Cyanobacteria and Cyanotoxins: Engineering Viewpoints. Open Access Library Journal, 7, e6363.

[56] Ghernaout, D. and Elboughdiri, N. (2020) Eliminating Cyanobacteria and Controlling Algal Organic Matter-Short Notes. Open Access Library Journal, 7, e6252. https://doi.org/10.4236/oalib.1106252

[57] Ghernaout, D. and Elboughdiri, N. (2020) Removing Antibiotic-Resistant Bacteria (ARB) Carrying Genes (ARGs): Challenges and Future Trends. Open Access Library Journal, 7, e6003. https://doi.org/10.4236/oalib.1106003

[58] Ghernaout, D. and Elboughdiri, N. (2020) On the Other Side of Viruses in the Background of Water Disinfection. Open Access Library Journal, 7, e6374.

[59] Ghernaout, D. and Elboughdiri, N. (2020) Disinfecting Water: Plasma Discharge for Removing Coronaviruses. Open Access Library Journal, 7, e6314.

https://doi.org/10.4236/oalib.1106314

[60] Ghernaout, D., Elboughdiri, N. and Al Arni, S. (2020) New Insights towards Disinfecting Viruses-Short Notes. Journal of Water Reuse and Desalination, 10, 173-186. https://doi.org/10.2166/wrd.2020.050

[61] Ahmad, N.A., Goh, P.S., Yogarathinam, L.T., Zulhairun, A.K. and Ismail, A.F. (2020) Current Advances in Membrane Technologies for Produced Water Desalination. Desalination, 493, Article ID: 114643. 
https://doi.org/10.1016/j.desal.2020.114643

[62] Jones, P.H. and Tompeck, M.A. (2006) Water Treatment. In: Pfafflin, J.R. and Ziegler, E.N., Eds., Encyclopedia of Environmental Science and Engineering, 5th Edition, CRC Press, Taylor \& Francis Group, Boca Raton, 1311.

https://doi.org/10.1201/NOE0849398438.ch87

[63] Bermuda, Black Mangrove (Avicennia germinans). https://environment.bm/black-mangrove\#: :text=Black\%20Mangrove\%20(Avicenn ia\%20germinans)\&text=If\%20you\%20look\%20closely\%20at, that $\% 20$ would $\% 20$ kill \%20other\%20plants

[64] Laborde, H.M., França, K.B., Neff, H. and Lima, A.M.N. (2001) Optimization Strategy for a Small-Scale Reverse Osmosis Water Desalination, System Based on Solar Energy. Desalination, 133, 1-12. https://doi.org/10.1016/S0011-9164(01)00078-9

[65] Fiorenza, G., Sharma, V.K. and Braccio, G. (2003) Techno-Economic Evaluation of a Solar Powered Water Desalination, Plant. Energy Conversion and Management, 44, 2217-2240. https://doi.org/10.1016/S0196-8904(02)00247-9

[66] Ghernaout, D. (2020) Electrocoagulation as a Pioneering Separation Technology-Electric Field Role. Open Access Library Journal, 7, e6702.

[67] Ghernaout, D. (2020) Electric Field (EF) in the Core of the Electrochemical (EC) Disinfection. Open Access Library Journal, 7, e6587.

[68] Ghernaout, D. (2020) Water Treatment Coagulation: Dares and Trends. Open Access Library Journal, 7, e6636.

[69] Côté, P., Masini, M. and Mourato, D. (2004) Comparison of Membrane Options for Water Reuse and Reclamation. Desalination, 167, 1-11. https://doi.org/10.1016/j.desal.2004.06.105

[70] Eke, J., Yusuf, A., Giwa, A. and Sodiq, A. (2020) The Global Status of Desalination: An Assessment of Current Desalination, Technologies, Plants and Capacity. Desalination, 495, Article ID: 114633. https://doi.org/10.1016/j.desal.2020.114633 